\title{
Effect of Rumen Content to Water Ratio in Biogas Production
}

\author{
${ }^{1}$ ANNOR, J; ${ }^{1,2 *}$ ADZITEY, F; ${ }^{1}$ ANSAH, T; ${ }^{3}$ AMPADU, OM \\ ${ }^{1}$ Department of Animal Science, Faculty of Agriculture, University for Development studies, P.O. Box TL 1882, Tamale, Ghana. \\ ${ }^{2}$ Department of Veterinary Science, Faculty of Agriculture, University for Development studies, P.O. Box TL 1882, Tamale, Ghana \\ ${ }^{3}$ Department of Agricultural Mechanization and Irrigation, University for Development studies, P.O. Box TL 1882, Tamale, Ghana \\ ${ }^{*}$ Corresponding Author: Email: adzitey@yahoo.co.uk; Tel +233249995310
}

\begin{abstract}
Biogas technology is widely used as a better alternative in the handling of waste in many societies in the world. This study was conducted to investigate the effect of rumen content to water ratio in biogas production. An experiment was carried out using 75 litre capacity locally made anaerobic digester. Rumen contents were formulated in three proportions designated as T1, T2 and T3. T1 contained 30kg of rumen contents and 30 litres of tap water; T2 contained $20 \mathrm{~kg}$ of rumen contents and 40 litres of tap water; and T3 contained $40 \mathrm{~kg}$ of rumen contents and 20 litres of tap water. Each proportion was duplicated and the whole experiment was triplicated for 20 days each. The $\mathrm{pH}$, substrate, ambient temperatures and the biogas produced were recorded in two days' interval up to the 20 days. The result obtained from the study showed that there were significant differences $(\mathrm{P}<0.05)$ in the average $\mathrm{pH}$ and the biogas produced. The $\mathrm{pH}$ of T2 (6.97) was significantly higher than that of T1 (6.80) and T3 (6.81). The biogas produced by T3 was significantly higher than that of T1 and T2. T3 produced the highest average volume of $16.70 \mathrm{~m}^{3}$ biogas per kilogram of rumen content and the highest percentage $(56.4 \%)$ of methane. There were no significant differences $(\mathrm{P}>0.05)$ in the average substrate and ambient temperatures, and the volume of $\mathrm{CO}_{2}$ produced. This study revealed that it is more efficient to produce biogas using $40 \mathrm{~kg}$ of rumen contents and 20 litres of tap water than producing biogas with $30 \mathrm{~kg}$ of rumen contents and 30 litres of tap water or $20 \mathrm{~kg}$ of rumen contents and 40 litres of tap water.
\end{abstract}

\section{DOI: https://dx.doi.org/10.4314/jasem.v22i8.18}

Copyright: Copyright $\odot 2018$ Annor et al. This is an open access article distributed under the Creative Commons Attribution License (CCL), which permits unrestricted use, distribution, and reproduction in any medium, provided the original work is properly cited.

Dates: Received: 15 June 2018; Revised: 20 July: 2018; Accepted: 18 August 2018

Keywords: biogas, $\mathrm{pH}$, rumen, temperature, water,

The most fascinating feature of civilised communities is the abundant availability of energy for domestic, agricultural and industrial purposes (Baki, 2004). Renewable energy effectively uses natural resources such as sunlight, wind, rain, tides and geothermal heat, which may be naturally replenished. The production of biogas from renewable resources is becoming a prominent feature of most developed and developing countries of the world. Biogas is produced when bacteria degrade biodegradable materials in the absence of oxygen, in a process known as anaerobic digestion (Verma, 2011; Global Alliance for Clean Cookstoves, 2018). Animal wastes can be used as sources of nutrient, feed ingredients to microorganisms and as fuel energy source. Biogas plant can be built by using materials which are locally available in most developing countries (Baki, 2004). Global primary energy consumption increased in 2015 by $1.0 \%$, which was similar to 2014 but well below the 10 -year average of $1.9 \%$, even though fossil fuel prices fell in 2015 in all regions (Olivier et al., 2016). Methane from ruminant livestock (enteric fermentation) is the largest biogenic source within agriculture sector (Environmental Protection Agency,
2009). Methane is a natural phenomenon in the ruminant rumen and they emit methane as part of their natural digestive processes (Environmental Protection Agency, 2009).

Rumen is the home of billions of microbes including bacteria, methanogens, protozoa, and fungi. These microbes breakdown feed to produce volatile fatty acids (VFAs), carbon dioxide, ammonia, and methane. The VFAs are used by the animals as energy source while the produced gases are removed by eructation (Environmental Protection Agency, 2009; Iqbal et al., 2008). According to Energy Commission (2006), Ghana government will promote biogas for heating in institutional kitchens, laboratories, hospitals, boarding schools and barracks. The Strategic National Energy Plan (SNEP) for Ghana is to achieve $1 \%$ penetration of biogas for cooking in hotels, restaurants and institutional kitchens by 2015 and $2 \%$ by 2020 . The associated harmful environmental, health and social effects with the use of traditional biomass and fossil fuel has enhanced the growing interest in the search for alternate cleaner source of energy globally. 
Ghana depends largely on wood as a source of fuel contributing about $72 \%$ of the primary energy supply with crude oil and hydro making up the rest (Arthur $e t$ al., 2011). There are vast biomass resources generated at the Tamale abattoir that have the potential for use as feedstock for biogas production to reduce the over reliance on wood fuel which will help to reduce greenhouse gas emissions that contributes to climate change. However, the waste generated from the abattoir is discharged into the community which creates an unbearable stench and a huge discomfort to the surrounding community. This work therefore sought to provide one of the sustainable solutions for the use of the waste produced at the Tamale Abattoir. This work aimed at producing biogas from rumen content, determining the $\mathrm{CN}$ ratio of rumen content and the composition of the biogas produced.

\section{MATERIALS AND METHODS}

Study area: The rumen contents were obtained from Tamale Abattoir in Shishegu, a suburb of Tamale Metropolis. Tamale is found within the Guinea Savannah belt (Ghana Statistical Services, 2000; Adzitey et al., 2016). The Metropolis is located on longitude $09^{\circ} 24^{\prime} 27^{\prime \prime}$ North and latitude $00^{\circ} 51^{\prime} 12^{\prime \prime}$ West, and occupies an area of approximately $750 \mathrm{~km}^{2}$ (Anonymous, 2018). Tamale is the third most populous settlement in Ghana, with a total population of 537,986 people and a population density of $480.77 / \mathrm{km}^{2}$ (Anonymous, 2018). The daily mean temperature $\left({ }^{\circ} \mathrm{C}\right)$, average precipitation $\mathrm{mm}$ (inches) and average relative humidity (\%) are 27.9, 1090 and 60, respectively (Ghana Statistical Services, 2000; Anonymous, 2018). The rumen contents were analysed for the carbon/nitrogen $(\mathrm{C} / \mathrm{N})$ content at the Spanish Laboratory and the production of the biogas was conducted at Mechanization Warehouse of the University for Development Studies, Nyankpala Campus.

Sample collection and preparation: Fresh rumen contents from cattle were collected from the Tamale Abattoir in Shishegu immediately after slaughter into a clean container. The container containing the rumen contents were transported immediately to the Mechanization Warehouse of University for Development Studies, Nyankpala Campus. A weighing balance was used to determine the mass of rumen content and that made up the total solid for particular fermenting sample.

Preparation of rumen content for biogas production: Rumen contents were formulated in three proportions designated as $\mathrm{T} 1, \mathrm{~T} 2$ and $\mathrm{T} 3$. T1 contained $30 \mathrm{~kg}$ of rumen contents and 30 litres of tap water; $\mathrm{T} 2$ contained $20 \mathrm{~kg}$ of rumen contents and 40 litres of tap water; and
T3 contained 40kg of rumen contents and 20 litres of tap water. Each proportion was duplicated and the whole experiment was run thrice.

Experimental set-up: All apparatuses were properly washed with tap water and allowed to dry overnight. A set of 6 locally made digesters (75 litre capacity) and 6 Buckner volumetric flasks $(1000 \mathrm{ml})$ were used. Each Buckner volumetric flask contained brine solution and was connected to a particular digester by means of a connecting tube, and on the other side, connected to a conical flask by means of another connecting tube. The biogas produced in the digester by fermentation passed through the connecting tube to the Buckner volumetric flask containing brine solution and from there it entered into the gas holder. The pressure of the biogas produced caused a displacement of the gas holder. The displacement height of the gas holder was measured every two days till the 20th day. The digester was operated at ambient temperature and a thermometer was used to measure the temperature. The average temperature was calculated and taken to be the operating temperature. A digital $\mathrm{pH}$ meter was used to determine the $\mathrm{pH}$ of the fermenting sample.

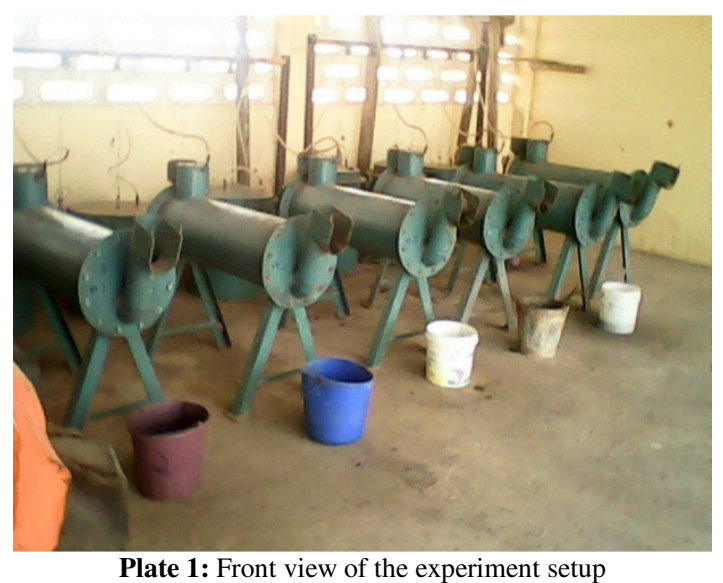

Production of biogas: Six Anaerobic Digesters labeled 01, 02, 03, 04, 05 and 06 were used and arranged as seen in plate 1 . The reactors were fed with a total of $60 \mathrm{~kg}$ of the substrate made up of rumen content and water. +++. The following parameters were measured in two days' interval: temperature, $\mathrm{pH}$, volume of gas produced, $\mathrm{CH}_{4}, \mathrm{CO}_{2}$, and $\mathrm{pH}$. The experiments were allowed a retention period of twenty days (20 days).

Measurement, analyses and testing of biogas: Measurements of gas volumes were done using a water displacement method (Patil et al., 2011), where the displaced heights were measured. Upon production the biogas was analyzed for methane and carbon dioxide contents using the Status Mentor PGD3-IR Gas Detector, United Kingdom. After the biogas was 
produced it was tested for its ability to burn. A connecting tube was used to connect the gas holders and lighted.

Determination of nitrogen and organic carbon: Determination of total nitrogen (crude protein) and organic carbon were conducted using the Kjeldal method and Walkley-Black wet oxidation method, respectively (Kjeldahl, 1883; Nelson and Sommers, 1996).

Data analysis: Data obtained was subjected to analysis of variance using (ANOVA) GenStat $4^{\text {th }}$ Edition. Means were separated at 5\% significance level.

\section{RESULTS AND DISCUSSION}

Volume of gas, methane and carbon dioxide: The results obtained for the analysis of the rumen content to water ratio in the production of biogas is shown in Table 1 . There was significant difference $(\mathrm{P}<0.05)$ in the volume of gas produced. Volume of gas produced by T2 $\left(16.70 \mathrm{~m}^{3}\right)$ was significantly higher $(\mathrm{P}<0.05)$ than that of T1 $\left(12.02 \mathrm{~m}^{3}\right)$ and $\mathrm{T} 0\left(10.72 \mathrm{~m}^{3}\right)$. There was also significant difference $(\mathrm{P}<0.05)$ in the average methane produced. Methane produced by T2 $\left(9.42 \mathrm{~m}^{3}\right)$ was also significantly higher $(\mathrm{P}<0.05)$ than $\mathrm{T} 0$ $\left(5.83 \mathrm{~m}^{3}\right)$ and $\mathrm{T} 1\left(5.69 \mathrm{~m}^{3}\right)$. There was no significant difference $(\mathrm{P}>0.05)$ in the average carbon dioxide produced.

Table 1: Mean of the biogas produced for the various treatments

\begin{tabular}{llllll}
\hline Parameter & & & & S.E. \\
$\mathrm{s}$ & $\mathrm{T} 0$ & $\mathrm{~T} 1$ & $\mathrm{~T} 2$ & $\mathrm{D}$ & P-VALUE \\
\hline Vol. of & 10.7 & 12.0 & & 2.03 & \\
gas $\left(\mathrm{m}^{3}\right)$ & $2^{\mathrm{a}}$ & $2^{\mathrm{a}}$ & $16.70^{\mathrm{b}}$ & 5 & 0.028 \\
& & 5.69 & & 1.05 & \\
$\mathrm{CH} 4\left(\mathrm{~m}^{3}\right)$ & $5.83^{\mathrm{a}}$ & $\mathrm{a}$ & $9.42^{\mathrm{b}}$ & 7 & 0.005 \\
$\mathrm{CO} 2\left(\mathrm{~m}^{3}\right)$ & 3.5 & 7.2 & 5.6 & 2.99 & 0.48 \\
& & 6.97 & & 0.05 & \\
pH & $6.80^{\mathrm{a}}$ & $\mathrm{b}$ & $6.81^{\mathrm{a}}$ & 33 & 0.014 \\
Sub. & & & & & \\
Temp. ${ }^{\circ}$ & 34.4 & 34.0 & & 0.59 & \\
C) & 4 & 1 & 33.7 & 6 & 0.477 \\
Amb. & & & & & \\
Temp. ${ }^{\circ}$ & 35.3 & 35.4 & & 0.72 & \\
C) & 6 & 6 & 35.44 & 5 & 0.99 \\
\hline
\end{tabular}

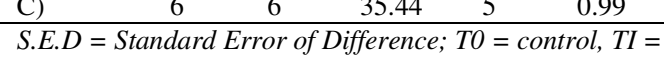
treatment $1, T 2=$ treatment 2 $p H$ : The $\mathrm{pH}$ for $\mathrm{T} 0, \mathrm{~T} 1$ and $\mathrm{T} 2$ were $6.80,6.97$ and 6.81 , respectively. There was statistical difference $(\mathrm{P}$ $<0.05)$ in the average $\mathrm{pH}$ recorded. There was statistically difference $(\mathrm{P}<0.05)$ in the average $\mathrm{pH}$ recorded in the digesters. This may be as a result of anaerobic fermentation taking place. According to Deublein (2008) anaerobic bacteria require a natural environment and thus, $\mathrm{pH}$ ranging from 6.7-7.5 is required for optimum biogas production. This was explained in terms of Shellford's law of tolerance which stated that, the occurrence of any organism in any environment is determined not only by availability of nutrients but also by various physicochemical factors (Oyeleke et al., 2003). Therefore, as the medium tend to become acidic, non-acid tolerance organisms will be replaced by acid tolerant organisms

Substrate and ambient temperature: There was no statistically difference $(\mathrm{P}>0.05)$ in the average substrate and ambient temperature recorded as shown in Table 1. The average temperature in the digester recorded during the experiments was $34.44^{\circ} \mathrm{C}$ for $\mathrm{T} 0$ $34.01^{\circ} \mathrm{C}$ for $\mathrm{T} 1$ and $33.70^{\circ} \mathrm{C}$ for $\mathrm{T} 2$. There were no significant differences $(\mathrm{P}>0.05)$ in the average ambient and substrate temperature recorded. The study agreed with that of Yadvika et al. (2004), who reported that in nature the formation of methane occurs at mesophilic temperature range of $\left(30-40{ }^{\circ} \mathrm{C}\right)$. In general, high temperature gives a higher methane production rate and allows higher loading rates, thus decreasing the reactor volume needed for a specific material (Yadvika et al., 2004). The average substrate temperature over the duration of anaerobic digestion has no negative effects on the ambient temperature according to Cioabla et al. (2012).

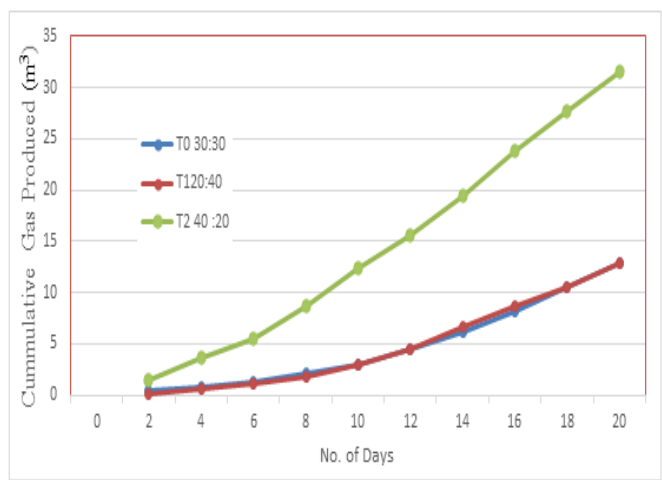

Fig 1: Cumulative gas produced.

From Figure 1, the proportion 40:20 that is, rumen content: water, respectively recorded the highest volume of gas produced. The gas produced from the proportions 30:30 (T0) and 20:40 (T1) were similar (Figure 1). 
Figure 2 shows that, T2 (40:20) that is, rumen content: water, respectively recorded the highest amount of methane gas produced. It was followed by T1 (20:40). T0 (30:30) recorded the lowest amount of methane produced.

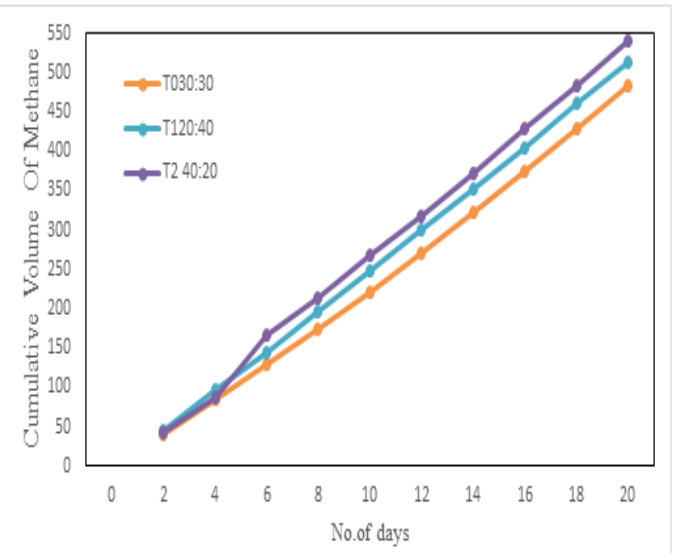

Fig 2: The cumulative volume of methane

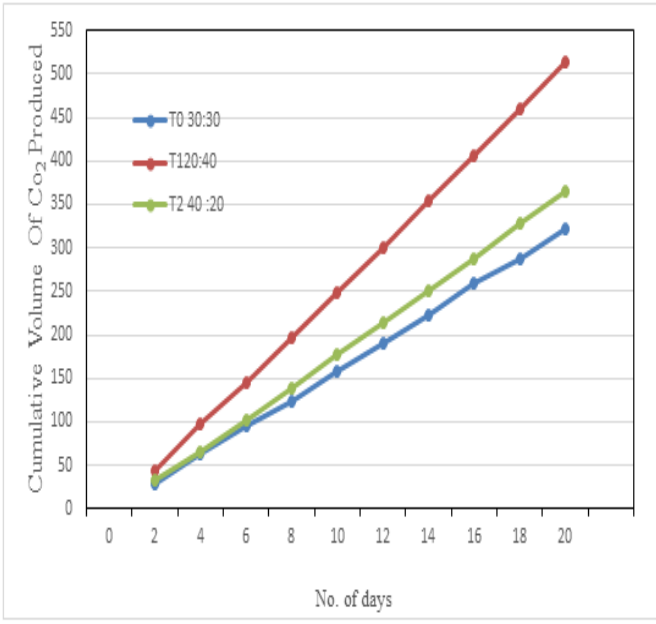

Fig 3: Cumulative volume of $\mathrm{CO}_{2}$ produced

The result revealed that, T1 (20:40) rumen content: water ratio produced the highest emission of carbon dioxide from day 2 to day 20 of digestion (Figure 3 ). It was followed by T2 (40:20) and T0 (30:30).

Carbon: nitrogen ratio: Carbon and nitrogen are the main nutrients required by micro-organisms (Doerr and Lehmkuhl, 2008). The optimum $\mathrm{C} / \mathrm{N}$ ratio for biogas production is 20 to 35:1 (Doerr and Lehmkuhl, 2008). The calculated $\mathrm{C} / \mathrm{N}$ ratio obtained from this study was $35: 1.48$.
This proportion fell within the recommended range of 20 to $35: 1$. If the $\mathrm{C} / \mathrm{N}$ ratio is very high, the nitrogen will be consumed rapidly by methanogens for meeting their protein requirements and will no longer react on the left-over carbon content of the material. On the other hand, if the $\mathrm{C} / \mathrm{N}$ ratio is very low, nitrogen will be liberated and accumulated in the form of ammonia, $\mathrm{CH}_{4}$ will increase the $\mathrm{pH}$ value of the content in the digester. Thus affecting the growth and development of the methanogens in the bioreactor. Sayibu and Ampadu (2015) studied the effectiveness of biogas production from slaughter waste and found that a carbon to nitrogen ratio of 1:1 produced 27.92litres of biogas per kilogram waste, while 1:2 gave 31.46litres per kilogram of waste. These values were higher than the present study. However, we used rumen content from only cattle while they used wastes from different animal species and materials.

The flammability of the methane produced: To show that biogas was produced, flame test was carried out using the gas produced from the bio-digesters. The connecting tube was used to connect the gas holders and lighted. The test was carried out in a dark room and the gas was found to be flammable. Plate 2 shows that the gas produced in this study can burn or produce flame. A connecting tube was used to connect the gas holders and lighted.

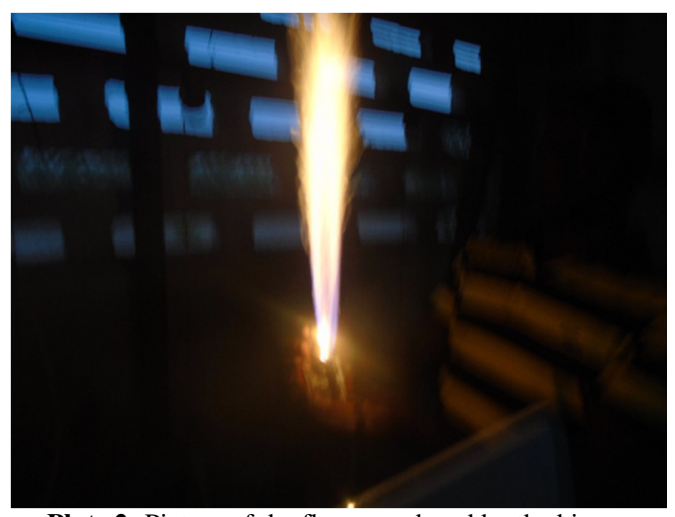

Plate 2: Picture of the flame produced by the biogas

The composition of biogas: Treatment 2 (2:1) produced the highest volume of $16.70 \mathrm{~m}^{3}$ biogas per kilogram of rumen content. T0 (1:1) ratio produced $10.72 \mathrm{~m}^{3}$ of biogas per kilogram of rumen content, while $\mathrm{T} 1$ (1:2) produced $12.02 \mathrm{~m}^{3}$ of biogas per kilogram of rumen content. The analysis of the biogas shows that the mixing ratio of $2: 1$ produced a highest percentage of methane $56.4 \%$ and carbon dioxide $33.5 \%$.

The 1:1 produced $47.3 \%$ of methane and the lowest percentage of carbon dioxide $32.4 \%$. The $1: 2$ ratio produced the lowest percentage of methane $47.3 \%$ and 
highest percentage of $\mathrm{CO}_{2} 49 \%$. The results of the study agree with the finding of Teodorita et al. (2008), who reported that biogas compose of $50-75 \%$ methane and $25-45 \%$ carbon dioxide. It also agrees with the findings of Juniper (2005), who reported that biogas contains $55-75 \%$ methane.

The low production of methane by the $1: 1$ was probably due to the fact that the methanogens are either in their lag phase or undergoing a metamorphic growth process (Dhaghat, 2001; Iyagba et al., 2009).

According to Lalitha et al. (1994) and Bal and Dhaghat (2001) during lag phase or the initial stages of the overall process of biogas production, acid forming bacteria produce volatile fatty acids (VFA) resulting in declining $\mathrm{pH}$ and diminishing growth of methanogenic bacteria and methanogens.

Thus might cause the low production of methane by the $1: 1$ ratio. The mixing ratio of $2: 1$ produced more biogas probably because the microorganisms have more substrate to feed on.

Conclusion: In conclusion, it is more efficient to produce biogas using a mixture of $40 \mathrm{~kg}$ rumen contents to 20litres of water, as compared to $30 \mathrm{~kg}$ rumen contents to 30 litres of water, and $20 \mathrm{~kg}$ of rumen contents to 40 litres of water.

\section{REFERENCES}

Adzitey, F; Ashiagbor, CNK; Abu, H (2016). Prevalence and antibiotic susceptibility of Salmonella spp. from water sources in Tamale, Ghana. International Journal of One Health 2:2428.

Anonymous (2014). Tamale Metropolis. Available from: https://en.wikipedia.org/wiki/Tamale, Ghana; 2014. Last accessed on 25-04-2018.

Arthur R; Baidoo, MF; Antwi, E. (2011). Biogas as a potential renewable energy source: A Ghanaian case study. Renewable Energy 36, 1510-1516.

Baki, AS (2004). Isolation and identification of microbes associated with biogas production at different retention time using cow dung. M.Sc. dissertation, Usmanu Danfodiyo University Sokoto, and Nigeria.

Cioabla, AE; Lonel, L; Dumitrel, GA; Popescu F (2012). Comparative study on factors affecting anaerobic digestion of agricultural vegetal residues. Biotechnology Biofuels 5, 39.
Deublein, D; Steinhauser, A (2008). Biogas from waste and renewable resources, published by the Deutsche National bibliothek.

Dhaghat, N.N. (2001). Up flow anaerobic sludge blanket reactor. Rev. Indian. J. Environ. Health, 43:1-82.

Doerr, B; Nate, L (2008). Methane digester. Available at: https://www.scribd.com/ document/355040197/Methane-Digesters-pdf. Last accessed on 06/06/20118.

Energy Commission (2006). Strategic national energy plan (2006-2020) and Ghana energy policy. Accra, Ghana.

Environmental protection agency (2009). Inventory of US greenhouse gas emission and sink, 430-R-09004.

Ghana Statistical Service (2000). 2000 Population and Housing Census. Available at: http://statsghana.gov.gh/nada/index.php/catalog/3. Last accessed on 06/06/20118.

Global Alliance for Clean Cookstoves (2018). Biogas. Available at: https://cleancookstoves.org/binarydata/TECHNOLOGY_FUELS/document/000/000 /6-1.pdf. Last accessed on 06/06/20118.

Iyagba, ET; Mangibo, IA; Mohammed, YS (2009). The study of cow dung as co-substrate with rice husk in biogas production. Scientific Research and Essays 4, 861-866.

Juniper (2005). 'MBT A Guide for Decision Makers Processes, Policies and Markets 'Report Published March 2005.

Kjeldahl, J (1883). "Neue Methode zur Bestimmung des Stickstoffs in organischen Körpern" (New method for the determination of nitrogen in organic substances). Zeitschrift für analytische Chemie, 22:366-383.

Iqbal, MF., Cheng, YF; Zhu, WY; Zeshan, B (2008). Mitigation of ruminant methane production. Current strategies, constraints, and future options. Laboratory of Gastrointestinal Microbiology, College of Animal Science and Technology, Nanjing.

Nelson, PW; Sommers, CE (1996). Total C, organic C and organic matter. In: PAGE, AL (Ed.). Methods of soil analysis. Part 2. Chemical methods. Madison: SSSA, pp. 539-579. 
Olivier, JGJ; Janssens-Maenhout, G; Muntean, M; Jeroen, AHW (2016). Trends in global $\mathrm{CO}_{2}$ emissions 2016 report. Available at: http://edgar.jrc.ec.europa.eu/news_docs/jrc-2016trends-in-global-co2-emissions-2016-report103425.pdf. Last accessed on 06/06/20118.

Oyeleke, SB; Onigbajo, HO; Ibrahim, K (2003). Degradation of animal wastes (cattle dung) to produce methane (cooking gas). Proceeding of the eighth annual Conference of Animal Science of Association of Nigeria (ASAN), pp. 168-169.

Patil, JH; MALourdu, AR; Gavimath, CC (2011). Study on effect of pre-treatment methods on biomethanation of water hyacinth. International Journal of Advanced Biotechnology and Research 2: 143-147.
Sayibu, SW; Ofoso, MA (2015). Effectiveness of biogas production from slaughter waste using two mixing ratios (waste: water ratio of $1: 1$ and $1: 2$ ). J. Nat. Sci. Res. 5:25-31.

Teodorita, Al; Seadi, DR; Heinz, P; Michael, K; Tobias, F; Silke, V; Rainer, J (2008). Biogas handbook. ISBN 978-87-992962-0-0, Edited by Teodorita.

Verma S (2012). Anaerobic digestion of biodegradable organics in municipal solid wastes. Available at: http://www.seas.columbia.edu/earth/vermathesis.p df. Last accessed on 06/06/20118.

Yadvika, S; Sreekrishnan, TR; Kohli, S; Rana, V (2004). Enhancement of biogas production from solid substrates using different technique. Bioresource Technology 95:1-10. 